\title{
Total syntheses of oxygenated brazanquinones via regioselective homologous anionic Fries rearrangement of benzylic $\mathbf{O}$-carbamates
}

\author{
Glaucia Barbosa Candido Alves Slana, Mariângela Soares de Azevedo, \\ Rosângela Sabattini Capella Lopes, Cláudio Cerqueira Lopes* \\ and Jari Nobrega Cardoso
}

\section{Full Research Paper}

\section{Address:}

Instituto de Química, Universidade Federal do Rio de Janeiro, CT, BI

A/508, 21949-900 Rio de Janeiro - RJ, Brazil

\section{Email:}

Glaucia Barbosa Candido Alves Slana - glaucia@gmx.net;

Mariângela Soares de Azevedo - mari@unir.br;

Rosângela Sabattini Capella Lopes - iqg02022@acd.ufrj;

Cláudio Cerqueira Lopes* - iqg02022@acd.ufrj;

Jari Nobrega Cardoso - jari@iq.ufrj.br

* Corresponding author
Beilstein Journal of Organic Chemistry 2006, 2, No. 1. doi:10.1186/1860-5397-2-1

Received: 11 October 2005

Accepted: 21 February 2006

Published: 21 February 2006

(c) 2006 Slana et al; licensee Beilstein-Institut.

License and terms: see end of document.

\begin{abstract}
\section{Introduction}

The search for new synthetic routes for the total synthesis of biologically active natural products has been growing in recent years, often stimulated by the lack of synthetic drugs for the cure of diseases.
\end{abstract}

Using new variations of anionic aromatic chemistry, the total synthesis of oxygenated brazanquinones (1a-1c), derived from $\beta$-brasan, a natural product isolated from Caesalpina echinata, via carbamates $\mathbf{2 a - 2 c}$ is described.

In various biological tests, several natural and synthetic brazanquinones have shown high biological activity. Cheng [1,2] in his work, evaluated (in vitro) a series of brazanquinones and their inhibitory activity against a series of cancer cell lines. Their activity has been attributed to their structure, in which the two ring systems are coplanar, and has attracted considerable attention as interesting synthetic targets. [3-11] However, the routes described in the literature do not offer the possibility of facile syntheses of other oxygenated analogues.
In this present work, the versatility of a new variation of anionic aromatic chemistry developed in our research group [12] will be applied in the context of rapid and efficient construction of these bioactive compounds for future biological evaluation.

The emerging carbanionic aromatic chemistry (anionic orthoFries, [13] homologous anionic Fries, [14] remote anionic Fries rearrangements [15] and carbamoyl Baker-Venkataraman reaction [16]) originating from the Directed ortho Metalation (DoM) strategy, [17] offer a mild and regioselective complement to classical Friedel-Crafts approaches for the rational construction of polysubstituted aromatics, biaryls, and several classes of heterocycles (Figure 1). 
<smiles>CCNC(=O)COc1ccccc1CC</smiles>

\section{Anionic} ortho-Fries<smiles>CCN1CCC(=O)Oc2ccccc2C1=O</smiles>

Carbamoyl

Baker-Venkataraman<smiles>[R]C1(CC)NC(=O)Cc2ccccc2O1</smiles>

$\mathrm{R}=\mathrm{H}, \mathrm{Ph}$<smiles>[R3]c1cccc2c1OCC(=O)N(CC)c1ccccc1-2</smiles>

\section{Remote} anionic Fries

Homologous anionic ortho-Fries

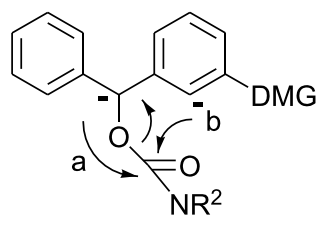

Path a: [1,2] -Wittig Path b: $[1,4]$-Wittig

Figure 1: Examples of carbanionic aromatic chemistry rearrangements.

In 1993, Gawley showed that $O$-benzylcarbamates in the presence of directed metalation groups (DMGs) undergo competitive anionic $[1,2]$ and $[1,4]$ Wittig - carbamoyl rearrangements (paths a and b) $[18,19]$ orientated by the groups R and DMGs (Figure 1).

Conceptual combination of path $\mathrm{b}$ and the well established tandem DoM route to anthraquinones and heteroanthra- quinones [20] led to the conjecture that, barring the competitive $[1,2]$-Wittig rearrangement, and one-pot route, $\mathbf{3} \rightarrow \mathbf{4} \rightarrow \mathbf{1}$, may be established in a direct manner without resort to DoM-derived benzamide intermediate, thereby establishing new carbonyl dianion equivalency 4 (see Scheme 1).

We now report the versatility of this strategy, in the context of rapid and efficient construction of new oxygenated brazan-<smiles>COc1cccc2c1OC1=C(C)C(=O)c3c(I)cccc3C12C(C)C</smiles>

1<smiles>[R1]NC(=O)OC(c1cc2ccccc2o1)c1ccccc1OC</smiles>

2

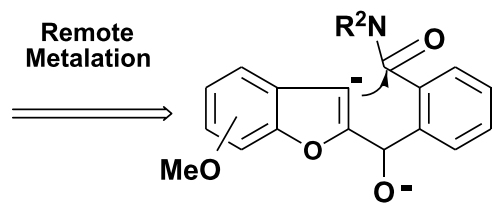

4

Anionic Homologous Fries

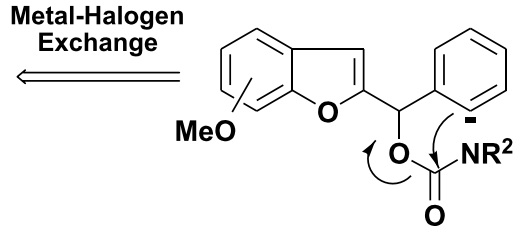

3 

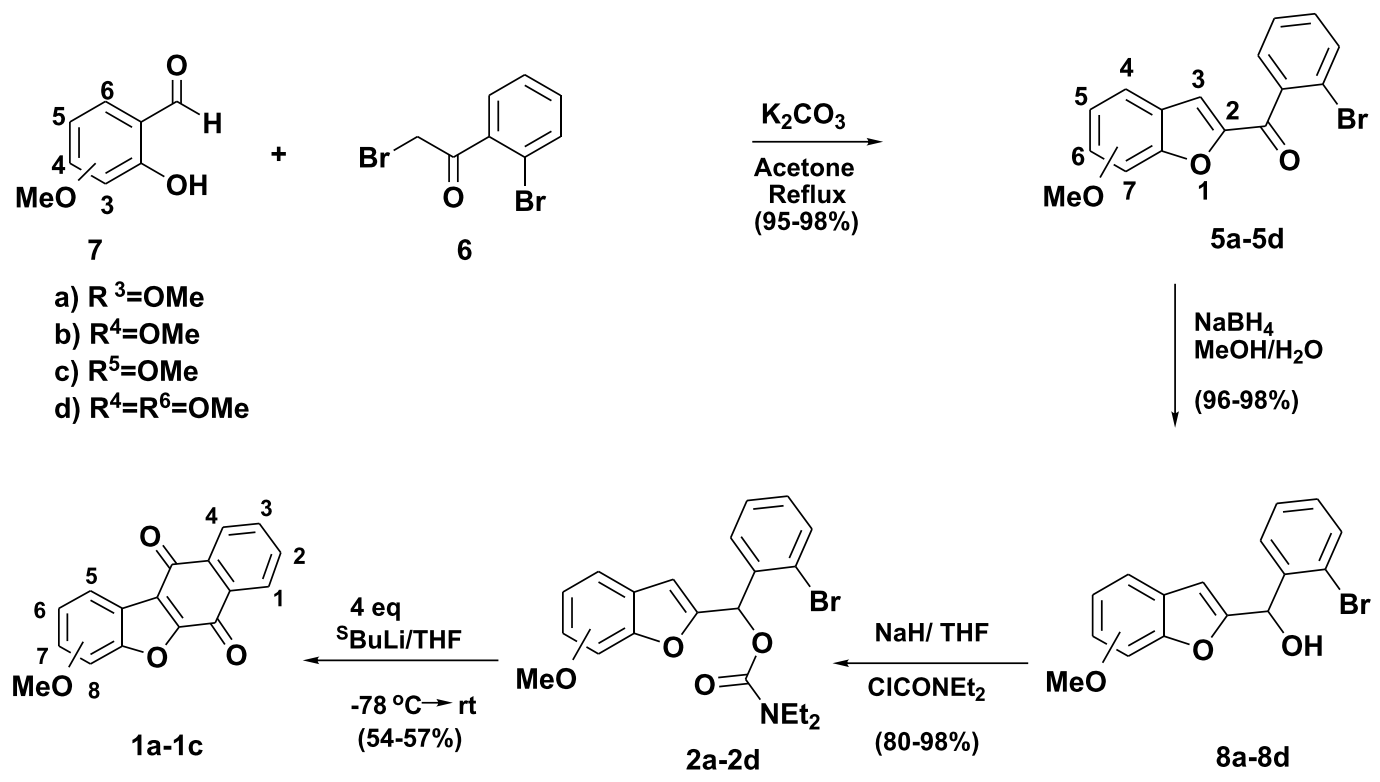

a) $R^{8}=O M e$
b) $R^{7}=O M e$
c) $R^{6}=O M e$

Scheme 2: Total syntheses of brazanquinones (1 a-c).

quinones (1a-1c) derived from $\beta$-brasan, a natural product isolated from Caesalpina echinata (Scheme 2).

\section{Results and discussion}

The synthesis of brazanquinones (1a-1c) is summarized in Scheme 2. According to our recent report, [12] the benzoylbenzofurans 5a-5d, were prepared in one-pot reaction from $\alpha$-bromoacetophenone $\mathbf{6}$ and ortho-hydroxybenzaldehydes 7a-7d in excellent yields (90-96\%). Reduction of benzoylbenzofurans $\mathbf{5 a - 5 d}$ in the presence of $\mathrm{NaBH}_{4}$ yielded the secondary alcohols 8a-8d, which upon treatment with $N, N$-diethylcarbamoyl chloride, and sodium hydride afforded the carbamates 2a-2d (Scheme 2).

The carbamates $\mathbf{2 a - 2 c}$ were cyclized in the presence of excess sec-BuLi in $\mathrm{THF}$ at $-78^{\circ} \mathrm{C}$ to afford the desired brazanquinones 1a-1c in reasonable yields (54\%-57\%) (Scheme 2).
The mechanism suggested by us and shown in Scheme 1, involves first the preparation of aryllithium intermediates 3 from the carbamates $\mathbf{2} \mathbf{a}-\mathbf{2} \mathbf{b}$ by the reversible metathesis reaction known [21-23] as the lithium-halogen exchange which has been widely employed for replacement of a bromine or iodine atom in a substrate by lithium. The intermediate 3 then undergoes an intramolecular anionic Fries rearrangement to intermediate 4, that was isolated in our previous results. [12]

Snieckus reported the remote metalation and cyclization of diethyl $\mathrm{N}$-methyl- $\mathrm{O}$-tolylanthranilamide to $\mathrm{N}$-methyl dibenzazepinone [24-26] developing a new regiospecific construction of condensed aromatics. We found this route very attractive and envisaged that by in situ treatment of intermediate 4 with the third equivalent of sec-BuLi, the cyclization to the desired quinone 1a-d would be obtained.

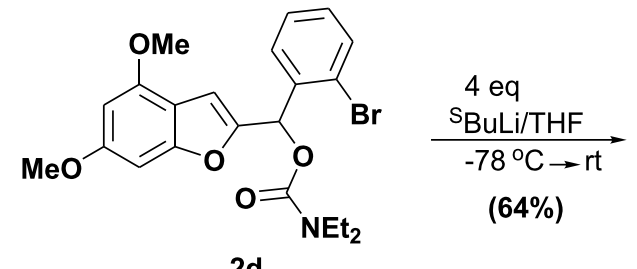

2d<smiles>COc1cc(OC)c2cc(C3OC(=O)c4ccccc43)oc2c1</smiles>

9

Scheme 3: Total syntheses of phthalide (9). 
One unexpected result was the formation of the phthalide 9 when the dimethoxy carbamate $\mathbf{2 d}$ was treated with excess sec$\mathrm{BuLi}$ under the same reaction conditions as $\mathbf{2 a - 2 c}$. Presumably, the presence of 4-OMe inhibits the cyclization by shielding the remote position (Scheme 3).

\section{Conclusion}

An efficient synthesis of brazanquinones (1a-c) using new variations of anionic aromatic chemistry was described. This methodology could be expanded in the future for the construction of new molecules with similar structures.

\section{Supporting Information}

\section{Supporting Information File 1}

contains the experimental section

[http://www.beilstein-journals.org/bjoc/content/

supplementary/1860-5397-2-1-S1.doc]

\section{Acknowledgments}

We thank FAPERJ and FUJB for financial support. CNPq, CAPES are acknowledged for scholarships to Glaucia B. C. A. Slana and Mariangela S. Azevedo.

\section{References}

1. Cheng, C. C.; Dong, Q.; Liu, D.-F.; Luo, Y.-L.; Liu, L. F.; Chen, A.-Y.; Yu, C.; Savaraj, N.; Chou, T.-C. J. Med. Chem. 1993, 36, 4108. doi:10.1021/jm00077a016

2. Crawford, P. W.; Carlos, E.; Ellegood, J. C.; Cheng, C. C.; Dong, Q.; LruJ, D. F.; Luof, Y. L. Electrochim. Acta 1996, 41, 2399. doi:10.1016/ 0013-4686(96)00020-5

3. Stadlbauer, W.; Kappe, T. Z. Naturforsch. 1975, 30b, 139.

4. El-Wareth, A.; Sarhan, A. O.; El-Dean, A. M.; Abdel-Monem, M. I. Monatsh. Chem. 1998, 129, 205.

5. Martínez, E.; Martínez, L.; Estévez, J. C.; Estévez, R. J.; Castedo, L. J. Med. Chem. Soc. 1978, 21, 291.

6. Bentley, K. W.; Robinson, R. J. Chem. Soc. 1950, 1353. doi:10.1039/ jr9500001353

7. Yoshida, K.; Adachi, T.; Oga, N.; Kubo, Y. Chem. Lett. 1990, 2049.

8. Simonitsch, E.; Eisenhuth, W.; Stamm, O. A. E.; Schmid, H. Helv. Chim. Acta 1960, 43, 58. doi:10.1002/hlca.19600430107

9. Chatterjea, J. N. Experientia 1953, 9, 256. doi:10.1007/BF02172434

10. Jha, O. P. J. Indian Chem. Soc. 1973, 44, 740.

11. Chatterjea, J. N.; Jha, O. P. J. Indian Chem. Soc. 1970, 47, 6.

12. Azevedo, M. S.; Lopes, C. C.; Lopes, R. S. C.; Alves, G. B. C. Synthesis 2004, 8, 1262-1268.

13. Sibi, M. P.; Snieckus, V. J. Org. Chem. 1983, 48, 1935. doi:10.1021/ jo00159a040

14. Kalinin, A. V.; Miah, M. A. J.; Chattopadhyay, S.; Tsukazaki, M.; Wicki, M. Synlett 1997, 7, 839.

15. Wang, W.; Snieckus, V. J. Org. Chem. 1992, 57, 424. doi:10.1021/ jo00028a004
16. Kalinin, A. V.; da Silva, A. J. M.; Lopes, C. C.; Lopes, R. S. C.; Snieckus, V. Tetrahedron Lett. 1998, 39, 4995. doi:10.1016/S00404039(98)00977-0

17. Snieckus, V. Chem. Rev. 1990, 90, 897. doi:10.1021/cr00104a001

18. Zhang, P.; Gawley, R. E. J. Org. Chem. 1993, 58, 3223. doi:10.1021/ jo00064a001

19. Superchi, S.; Sotomayor, N.; Maio, G.; Joseph, B.; Campbell, M. G.; Snieckus, V. Tetrahedron Lett. 1996, 37, 60.

20. Watanabe, M.; Snieckus, V. J. Am. Chem. Soc. 1980, 102, 1457. doi:10.1021/ja00524a059

For a tandem DoM route to anthraquinones and heteroanthraquinones based on initial benzamide-aromatic aldehyde condensation.

21. Wittig, G.; Pockels, D.; Dröge, H. Ber. Dtsch. Chem. Ges. B 1938, 71, 1903.

22. Gilman, H.; Jacoby, A. L. J. Org. Chem. 1938, 3, 108. doi:10.1021/ jo01219a003

23. Gilman, H.; Langham, W.; Jacoby, A. L. J. Am. Chem. Soc. 1939, 61, 106. doi:10.1021/ja01870a036

24. Fu, J. M.; Zhao, B. P.; Sharp, M. J.; Snieckus, V. J. Org. Chem. 1991, 56, 1683. doi:10.1021/jo00005a004

25. Wang, W.; Snieckus, V. J. Org. Chem. 1992, 57, 424. doi:10.1021/ jo00028a004

26. Wang, X.; Snieckus, V. Tetrahedron Lett. 1991, 32, 4879. doi:10.1016/ S0040-4039(00)93485-3

27. Still, W. C.; Michael, K.; Abhiji, M. J. Org. Chem. 1978, 4, 2923. doi:10.1021/jo00408a041

28. Watson, S. C.; Eastman, J. F. J. Organomet. Chem. 1967, 9, 165. doi:10.1016/S0022-328X(00)92418-5

\section{License and Terms}

This is an Open Access article under the terms of the Creative Commons Attribution License (http://creativecommons.org/licenses/by/2.0), which permits unrestricted use, distribution, and reproduction in any medium, provided the original work is properly cited.

The license is subject to the Beilstein Journal of Organic Chemistry terms and conditions:

(http://www.beilstein-journals.org/bjoc)

The definitive version of this article is the electronic one which can be found at: doi:10.1186/1860-5397-2-1 